\title{
4 Procedural justice, legitimacy, and social contexts
}

\author{
Anthony Bottoms and Justice Tankebe
}

\subsection{Introduction}

Most people can remember occasions when they have been treated unfairly by an authority figure-for example, a teacher, a boss, a police officer, an airport official, or a referee in a sports game. Perhaps that person refused to listen to what we were trying to explain to them; or perhaps they seemed to have already made up their mind without considering all the facts; or perhaps they made belittling personal remarks about us, or made an unkind joke at our expense. We might also remember occasions when the reverse has happened, and an authority figure has treated us very courteously and with a concern for our well-being, or has gone out of her way to master all the facts and carefully explain her decision.

In the world of academia, these matters are described as 'procedural justice' (or injustice), and there is now a large and rather technical literature on this topic. It is therefore worth reminding ourselves that this literature concerns an everyday phenomenon, of which we all have experience. That being the case, procedural justice (or injustice) is delivered in a wide variety of social contexts. It has to be said, however, that the empirical research literature on procedural justice (hereafter, 'PJ') has not always taken adequate account of the social contexts of the encounters that it seeks to study. We are therefore pleased to have been asked to contribute to a volume that, among other things, is seeking to redress this imbalance.

Within criminology, a further feature of the academic literature on PJ is that much of it is closely linked to analyses of the legitimacy of criminal justice authorities. Thus, it is very commonly claimed that when such authorities act with procedural justice, this enhances their legitimacy in the eyes of those they are dealing with; and it is sometimes claimed that PJ is the most important factor promoting such legitimacy.

Against this background, the analysis in this chapter will be developed in two main sections and a conclusion. In Section 4.2, we discuss PJ within the context of its relation to the legitimacy of criminal justice institutions and personnel. In so doing, we pay particular attention to the meaning of 'PJ' and of 'legitimacy', and we argue that understanding of both concepts is enhanced by seeing them through the lens of a theory of 'basic legitimation expectations'. That theory

DOI: $10.4324 / 9780429317248-7$ 
also suggests that factors other than PJ might contribute to the legitimacy of criminal justice authorities. In Section 4.3, we emphasise the social embeddedness of procedural justice and legitimacy. This leads us to consider how a citizen's social background, and his or her prior experiences with legal authorities, might shape understandings of, and reactions to, a current encounter with an authority figure; how the particular situational context of the current encounter might also be important; and why a distinction between 'good' and 'right' relationships between citizens and legal authorities is relevant in the study of PJ. In the conclusion, we argue that the contextual variability demonstrated in Section 4.3 suggests that PJ scholarship should in future pay greater attention to the social circumstances in which PJ is delivered, and therefore also to qualitative research methods.

Throughout, we will in particular consider PJ and legitimacy in the context of policing because that has been the principal focus of the empirical research literature. However, where appropriate we also introduce evidence from other criminal justice contexts, especially prisons.

\subsection{Procedural justice and legitimacy}

It is central to our argument that both procedural justice and legitimacy are, in a double sense, normative concepts. Within the framework of social and legal philosophy, they are normative in the sense that they offer reasons why legal authorities should behave in certain ways. Within the framework of descriptive social science (which, for the most part, aims to be morally neutral in its study of social processes), they also provide normative as opposed to instrumental explanations of human behaviour. ${ }^{1}$

In thus emphasising the doubly normative character of PJ and legitimacy, we are influenced by the analyses of the legal philosopher Neil MacCormick (2007), who pointed out that, descriptively speaking, human beings are inescapably 'norm-users, whose interactions with each other depend on mutually recognizable patterns that can be articulated in terms of right versus wrong conduct, or of what one ought to do in a certain setting' (p. 20). Building on his understanding of the indispensability of norms to everyday life, MacCormick further claimed that the central characteristic of a modern legal system is that it is a form of 'institutional normative order'-that is, it comprises a complex set of social institutions that, among other things, embody and proclaim standards of 'right versus wrong conduct, or of what one ought to do in a certain setting' (p. 11).

\subsubsection{Conceptual issues}

If law is institutional normative order, it follows that any attempt to understand people's orientations to legal authorities must include some consideration of the normative status of those authorities (Beetham 1991/2013). 
This thought immediately introduces the concept of legitimacy. Legitimate power has been well described, within the framework of social science, as power that is 'acknowledged as rightful by relevant agents, who include power-holders and their staff, those subject to the power and third parties whose support or recognition may help confirm it' (Beetham 2013, p. 19, emphasis in original). ${ }^{2}$ Among these 'relevant agents', those subject to the power are perhaps of special significance because of their potential vulnerability. This point has been illuminated in a posthumously published essay by the philosopher Bernard Williams. Williams (2005) argues that the 'first political question' in any society is always the 'securing of order, protection, safety, trust and the conditions of co-operation', because without a solution to this question people cannot satisfactorily pursue everyday routine activities such as economic production, trade, child care, and education (p. 3). However, as Geoffrey Hawthorn (2005, p. xii) pointed out in his introduction to Williams' essays, if a ruler with no moral scruples has access to effective state power, then 'putting a stop to disorder is not difficult'; but in those circumstances a solution to the 'first question' might well generate a further problem - that of living under despotism. This is why, in Williams' analysis, it is always reasonable for those subject to state power to 'ask what the nature of the state's protection and its price are to be and why, and they will want a reasonable reply' (Hawthorn 2005, p. xii). Raising such questions is described by Williams as making 'Basic Legitimation Demands', or BLDs. These so-called 'demands' indicate the kind of conditions that citizens consider will allow them to acknowledge state power as 'rightful'. Given this, we think they are perhaps better described as 'expectations' rather than 'demands' (or BLEs rather than BLDs) - that is, they indicate the expectations that the citizens of a given state have of rightful power-holders. Williams argues that the difference between legitimate and illegitimate power lies in the ability of power-holders to honour citizens' BLEs, to a reasonable extent, in particular state contexts. ${ }^{3}$ Crucially, he also claims that what people consider a satisfactory 'legitimation story' (i.e. an account that satisfies their BLEs) is historically variable. This implies that we can only hypothesise, rather than determine a priori, what the structure of legitimacy might look like in any given society; and such structures will probably vary both historically and geographically (for example, they will likely be different in a medieval theocracy and a modern liberal democracy).

How does PJ fit into this kind of analysis? It is now standard for scholars interested in PJ to describe it as referring to four aspects of the exercise of authority. A useful summary of this framework has recently been provided by Tom Tyler and Tracey Meares (2019):

First, people want a voice. The public wants [authorities] to allow people to express their views or tell their side of the story before determining policies or making decisions. Second, people care about neutrality. People want [authorities] to act in a transparent and impartial manner by making decisions based upon facts, not prejudices. Neutrality is also related to whether 
[authorities] explain what their policies are, and how they are being applied. Third, people want interpersonal respect. This includes respect for people's rights as citizens and for their dignity as people ... Fourth, people care about trustworthy motives. It is important to people to feel that [authorities] are motivated to do what is good for the people in their community. ${ }^{4}$

(p. 74, emphasis added)

In light of Bernard Williams' analysis, it is interesting to note that this account is couched in terms of what people 'want' or 'care about' in their dealings with legal authorities. Given this, it seems reasonable to argue that Tom Tyler, the leading academic proponent of PJ in relation to criminal justice, is here in effect claiming that the four identified aspects of PJ constitute (at least in liberal democracies such as the United States) four aspects of a basic legitimation expectation that authorities will act with procedural justice. If that is correct, it is potentially an important conceptual linkage of PJ theory to legitimacy theory. However, it leaves open the question of whether citizens might also have Basic Legitimation Expectations concerning other matters, which might also need to be satisfied before the authority is regarded as fully legitimate.

Tom Tyler's work has primarily focused on empirical analyses. Ever since his seminal book, Why People Obey the Law (Tyler 1990/2006), he has argued for a sequence of empirical links between PJ and legal compliance, approximately as follows: the procedurally just treatment of citizens by criminal justice (CJ) agents will lead citizens to form positive perceptions of PJ by CJ agents; this in turn will mean that citizens are more likely to recognise CJ agents as legitimate authorities; and, finally, this recognition of legitimacy will lead citizens to an enhanced compliance with law. ${ }^{5}$

A key explanatory question arising from this proposed sequence is: why are citizens who form positive perceptions of PJ by CJ agents more likely to regard those authorities as legitimate? The principal explanation that has been put forward in the PJ literature is the so-called 'group value model', originally developed by Lind and Tyler (1988), which postulates that human beings are social creatures who derive part of their understanding of themselves from how they are valued (or otherwise) by other members of the social groups to which they belongfrom families to the state. ${ }^{6}$ Tyler $(1990 / 2006)$ applied this theory to procedural justice in legal contexts in the following way:

When people approach authorities, their social standing and feelings of security within the group are on the line. They may have an experience that reaffirms their belief that they are valued, protected members of society ... they may also have an experience that makes them feel less valued and protected than they would like to believe ... Dealing with authorities clearly raises issues far beyond those connected with the issue to be decided ... When the police harass members of minority groups, the poor or the young, they are communicating to those groups that they have marginal social status.

(pp. 175-176) 
In our view, this is a compelling normative explanation as to why the exercise of procedural justice by legal authorities is likely to contribute to attributions of legitimacy. ${ }^{7}$ As will shortly be seen, however, we believe that other factors also often contribute to these attributions.

\subsubsection{Assessing procedural justice}

A technical question of some importance concerns how researchers can best measure the concept of procedural justice. In some criminal justice contexts, such as courts, PJ can in principle be observed directly, because courts are open to the public. But the bulk of PJ research has focused on the police, and here matters are more complicated, because many interactions between police and citizens have few if any witnesses. Most empirical research on PJ in policing contexts has therefore measured PJ by survey questions to people who have had some contact with the police. In such surveys, respondents are asked about (among other things) their overall satisfaction with the encounter, whether the police officer allowed the citizen to have a voice, whether the officer was polite and treated the citizen with respect, and so on. This might be described as a measure of 'subjective PJ' or 'perceived PJ'.

Recently, several researchers have published studies that attempt to get closer to what actually happens when police meet citizens (see, for example, JonathanZamir et al. 2015; McCluskey et al. 2019; Nawaz \& Tankebe 2018). The most interesting, and the most challenging, of these studies is by Worden and McLean (2017) in Schenectady, New York. These authors studied 411 police-citizen encounters where, uniquely, data about the same encounter were available both from the citizen's recollections in a standard survey and from independent coding of a video recording of the incident. As expected, these two data sources were positively correlated; but, much more surprisingly, the correlation was only 'weak to moderate' (p. 134), so that observed 'procedural justice and injustice together explained no more than 12 per cent of the variations in citizens' subjective experience' of PJ (p. 179). We should not jump to too many conclusions from a single study, but methodologically speaking this result does suggest that scholars should be cautious, at present, before they too readily assume that what might be described as 'subjective PJ' is identical to 'independently observed PJ'.

But suppose it turns out, after a number of further research studies, that these two concepts are consistently shown to be only weakly connected? Here, it is important to recall that Tyler's (1990/2006) hypothesised causal sequence is that 'observed PJ' leads to 'perceived PJ' leads to 'citizens' attributions of legitimacy' (see previous discussion). That being so, a result of the kind described would have no impact on the bulk of research findings about the relationship between PJ and legitimacy (other than to substitute 'perceived PJ' for 'PJ'), because the hypothesis has always been that perceived PJ leads to attributions of legitimacy. What such a result would do, however, is to open up a fresh strand of empirical research into why citizens' recollections of PJ are sometimes different 
from what actually happened; in other words, it would raise important questions about how police behaviour is socially perceived by citizens. We will return to this issue in Section 4.3.1 below.

\subsubsection{The Bottoms-Tankebe approach to criminal justice legitimacy}

In previous publications on legitimacy and criminal justice, we have advanced a number of propositions, two of which are of relevance in the current context. First, in a 2012 paper, we argued that 'legitimacy needs to be perceived as always dialogic and relational in character' (emphasis added). We elaborated the point as follows:

those in power (or seeking power) in a given context make a claim to be the legitimate ruler(s); then members of the audience ${ }^{8}$ respond to this claim; the power-holder might adjust the nature of the claim in light of the audience's response; and this process repeats itself ... [I]t is more like a perpetual discussion, in which the content of power-holders' later claims will be affected by the nature of the audience response.

(Bottoms \& Tankebe, 2012, p. 129)

At the time that we wrote that paper, we were not aware of Bernard Williams' conceptualisation of the 'basic legitimation demand', but it is clear that seeing legitimation as a continuing dialogue is highly congruent with the 'BLD/BLE' approach. ${ }^{9}$

A second main claim in our previous work has been that, at least in democratic societies, it is possible to identify four Basic Legitimation Expectations that seem likely to contribute to the structure of legitimacy of criminal justice agencies. This claim has an empirical element, because each of these four BLEs has been shown empirically to contribute to perceptions of legitimacy in some situations. However, we also argue that these empirical findings are coherently related to the definition of legitimacy as power that is 'acknowledged as rightful' (Beetham 2013 , p. 19). This is because each of the four matters can be seen as being appropriately raised as BLEs when citizens ask criminal justice authorities 'what the nature of the state's protection and its price are to be, and why' (Hawthorn 2005, p. xii).

One of these four suggested BLEs is procedural justice; the others are the lawfulness, distributive justice, and effectiveness of the relevant authorities (Bottoms \& Tankebe 2017; Tankebe 2013). Lawfulness concerns authorities' adherence to the rule of law; more specifically, to an expectation that they will exercise only those powers that are explicitly provided in law, and that they will act within the relevant legal boundaries. Distributive justice concerns the perceived fairness of criminal justice agencies in allocating resources and making key decisions (police stops, sentencing, parole, etc.) with regard to relevant social groupings. These groupings include race, gender, social class, political affiliation, and offence type. 
Distributive justice therefore 'raises questions regarding the evenness with which law enforcement and sanction is applied-whether justice outcomes are distributed fairly' (Peffley \& Hurwitz 2010, p. 71, emphasis in original). Finally, effectiveness is concerned with public expectations that criminal justice agencies should be reasonably effective in performing the tasks that they have been assigned. Effectiveness might be called into question if, for example, the police seem unable to address public safety satisfactorily in a particular area, or if a parole board regularly releases people who then commit serious offences.

In the research literature, the most contentious of these four matters as contributors to attributions of legitimacy have been distributive justice and effectiveness, ${ }^{10}$ and the debates around this matter have been partly empirical and partly conceptual.

The empirical debate has focused on the question 'which factor(s) is/are most important in generating legitimacy'? Some PJ scholars have claimed that procedural justice is always or almost always the most important, but this claim is becoming increasingly hard to sustain. For example, as regards effectiveness, there are now a number of studies, especially from African countries where the state is often weak, suggesting that (congruently with Williams' 'first political question') effectiveness in providing basic social order, rather than procedural justice, is the primary concern for citizens seeking legitimate governance (Tankebe 2009; Bradford et al. 2014; Akinlabi 2018). Similarly, as later sections of this chapter will show, there is now clear evidence that in some circumstances distributive justice or injustice is a more powerful explanation of the observed social phenomena than is procedural justice or injustice. Our own reading of the evidence is that there is no one factor that best promotes legitimacy in every context; instead, the importance of factors can and does vary in different social contexts.

The second debatable issue is conceptual. It arises from the fact that effectiveness and distributive justice both contain an outcome-oriented dimension, which some scholars have seen as making them necessarily instrumental in focus, and therefore distinct from the normative concept of legitimacy (see, for example, Sunshine \& Tyler 2003, p. 514). In our view, however, such a position is conceptually problematic. Certainly, distributive justice and effectiveness include a concern with outcomes, but that does not make them simply instrumental. For social behaviour to be instrumental, it needs to be arrived at by considering the future consequences of the behaviour-usually the anticipated future benefits or costs (financial or otherwise). Attributions of legitimacy, however, are not forward-looking: they are judgements about the current normative status of power-holders (Beetham 1991/2013); hence, they describe a positive or negative assessment by citizens of a power-holder's current moral right to exercise power (Bottoms \& Tankebe 2012; Coicaud 2002). Using that criterion, a police service that seems either ineffective, or biased against a particular ethnic group, might reasonably be considered by some citizens to have lost the moral right to exercise power. ${ }^{11}$ For example, the main concern of the Black Lives Matter movement in the United States has not been the fairness of the processes leading to 
police decisions to shoot African Americans, nor even the legality of police violence. Rather, what drives this movement is a deep concern and resentment about the unfairness of the very disproportionate representation of African Americans as victims in fatal police-civilian encounters. Thus, their ethical stance is not based on an instrumental (cost-benefit) calculation of future outcomes; rather, it is rooted in a deep moral concern about the apparent disregard by many police services of the statement in the 1776 American Declaration of Independence that 'all [human beings] are created equal ... with certain unalienable rights ... [including those of] life, liberty and the pursuit of happiness'. Black people in the US are continuing to express a 'basic legitimation expectation' that their police services should honour this principle; that police often seem not to be doing so (distributive unfairness) is therefore very much a matter of normative, not instrumental, concern.

In order to avoid misunderstanding about our proposed fourfold legitimacy structure, some clarificatory comments about it might be helpful. In a recent paper on legitimacy in policing, we described the structure in this way:

Legitimacy dialogues are always contingent on specific features of the time and place in which they occur ... and this means that the specifics of legitimation and legitimacy can be very variable. We have however suggested the enduring importance of procedural justice, distributive justice, effectiveness and lawfulness as guides to the delivery of legitimate policing ... [F]irm evidence can be cited that a failure to deliver on any one of these four matters has on some occasions led to a legitimacy deficit for a public police service.

(Bottoms \& Tankebe 2017, p. 88)

Two points about this statement are worth emphasising. First, the approach taken is empirical, so no claim is made that these four matters will always contribute to citizens' perceptions of criminal justice legitimacy in every cultural context (in some situations, they may not ${ }^{12}$ ). Nor is it claimed that no other factors will ever contribute to criminal justice legitimacy (very likely, in some situations they will, especially as more research is conducted in non-Western contexts). The claim is simply that each of these matters has been shown empirically to contribute to the formation of citizens' views about criminal justice legitimacy; hence those interested in building improved legitimacy should always consider the potential relevance of each of these matters in their particular situation. Second, the structure does not assume that all of its proposed contributors carry equal weight. On the contrary, depending on the social context, one or more of them might be of greater or lesser importance.

Finally, we should note that a recent empirical study in the United States provides some encouraging support for our fourfold model. Kearns et al. (2019), having noted that the academic literature contains varied theoretical approaches to the understanding of legitimacy, decided to survey the general population on this question. They therefore asked 1,900 US residents the open-ended question: 
'When thinking about the police, what does “legitimacy" mean to you?' Answers were mostly short (mean $=6.2$ words), but the researchers were able to code the responses into seven distinct categories, which varied very little across different ethnic groups. ${ }^{13}$ Overall, the most frequently mentioned category was 'follows the law' (mentioned by $37 \%$ of respondents); the other categories were 'honesty' (19\%), 'fairness' (11\%), 'right to govern' (11\%), 'effective' (9\%), 'moral/do right' $(9 \%)$, and 'protection' (5\%). As the authors note, these categories explicitly include each of the four dimensions in the Bottoms-Tankebe model ['follows the law'; 'fairness' (procedural and distributive) ${ }^{14}$; and 'effective'], although the proportion of respondents choosing some of these dimensions was small. As we interpret them, the categories also include one item ('right to govern') that is very close to academic definitions of legitimacy; two items ('honesty' and 'moral/do right') that could be subsumed under the heading of procedural justice; and one item ('protection') that could be subsumed under effectiveness. Since the research question was open-ended, with no prompting, the results of this study offer support for the view that each element of our proposed fourfold structure is regarded as a basic legitimation expectation by at least a proportion of ordinary citizens.

\subsubsection{Comment}

This initial section has focused on trying to understand the concepts of procedural justice and legitimacy more fully, and to show how they might be related. But in doing so, we have also, directly or by implication, raised a number of matters that require us to understand these concepts as necessarily social and relational in character. Indeed, the concept of legitimacy itself makes no sense except against the background facts that, first, human beings always live in groups; and second that for these groups to function adequately, some people have to be given the power to make certain decisions on behalf of the group, in order to promote the safety and well-being of its members. ${ }^{15}$ In turn, this leads those without power to express some 'basic legitimation expectations' to the power-holders, in order to try to ensure that the character of the power being exercised does not become unjust, or otherwise inappropriate. If power-holders do start to behave in ways that citizens consider to be unjust, people will not feel that they are being treated with proper dignity as members of the group or society. All this being the case, both PJ and legitimacy are deeply social as well as normative concepts. It is therefore now necessary to explore in more detail some of their social features.

\subsection{Social and situational contexts}

Employing a terminology used in economic sociology, it is possible to categorise two broad approaches to social-scientific research: formalist and substantivist. A formalist approach to social action isolates individuals from their socio-historical contexts and attempts to analyse their actions in an atomised fashion. Granovetter (1985, p. 490) identifies three characteristics of the formalist position: the 
transactors are previously unacquainted; they are unlikely to transact again, and information about the activities of either is unlikely to reach others with whom they might transact in the future. A substantivist approach, on the other hand, emphasises the embeddedness of social actions within specific socio-historical settings and within 'concrete, ongoing systems of social relations' (Granovetter 1985, p. 487).

No procedural justice research has all the characteristics of the formalist position. Nevertheless, because much of the PJ literature is survey-based, some of it does have a tendency to treat interactions between legal authorities and civilians as 'spot' encounters, atomised and without history, and lacking much consideration of broader social contexts and the current situational framework. From our dialogic perspective of legitimacy, this is a mistake: as we have argued above, legitimacy dialogues are always contingent on specific features of the place and time in which they occur. A substantivist view is therefore consistent with the insights from political science that there are always social forces and processes that shape the nature and outcomes of legitimacy dialogues (see Dunn 2013). Those forces and processes might, of course, operate at macro-, meso- or micro-social levels. However, given the focus of this volume on procedural justice, it is appropriate in this chapter to consider especially what happens when there are actual encounters (or a deliberate avoidance of encounters) between authority figures and citizens. Accordingly, our focus here is on micro- and meso-social issues. ${ }^{16}$

Our substantivist discussion will work with the useful distinction drawn by Worden and McLean (2017, Figure 6, p. 83) between the influence of 'citizens' backgrounds' and the influence of the current 'situational context' in which legitimacy-relevant encounters occur.

\subsubsection{Citizens' backgrounds, procedural justice and legitimacy}

We begin by exploring the possible relevance of citizens' normative beliefs. In Why People Obey the Law, Tyler (1990/2006) identified two different types of internalised obligation to obey authorities. These are legitimacy, and what he called 'personal morality', which was described as differing from legitimacy because it is 'not a feeling of obligation to an external ... authority', but instead 'an internalized obligation to follow one's personal sense of what is morally right or wrong' (pp. 25-26). Despite this conceptual distinction, however, Tyler noted that in some circumstances these two kinds of obligation might be empirically linked, because an individual's personal morality (e.g. his or her political beliefs) 'may or may not' lead him or her to ascribe legitimacy to the authorities in a given situation (p. 26). Much of the literature has paid only limited attention to possible links of this kind, but recently this topic has been more actively considered.

An important analysis in this vein was conducted by Mehozay and Factor (2017), using data from over 52,000 respondents to the European Social Survey (which covers 27 countries). The authors hypothesised that beliefs about the legitimacy of the police derive, to a significant extent, from what they term 'core 
normative values (i.e. notions of the good and virtuous life) that stem from deeply embedded cultural orientations through which individuals operate in and interpret the world' (p. 154). Four such categories of 'deep values' were identified, and described as liberal; republican-communitarian; ethno-national and religious-traditional. The analysis of survey responses showed that perceptions of the legitimacy of police were positive for individuals holding liberal or republican-communitarian worldviews, but they were negative for those holding ethno-national normative values. ${ }^{17}$ The authors also conducted an analysis in which respondents' views were aggregated on a national basis, which showed some important differences by country, both in dominant normative values and in assessments of police legitimacy. The results of the study are described as providing preliminary support for the authors' main hypothesis. Importantly, however, it is argued that if the theory underpinning that hypothesis receives fuller substantiation, this will show that 'even optimal [police] procedural conduct or efficiency may not affect the attitudes of some populations' (p. 172). At a theoretical level, the authors also argue that the 'core normative values' that they describe 'are so embedded and internalized that they become a sort of habit', which, they suggest, might explain why they have received little attention in the criminological literature, because habit is a compliance mechanism that 'seems to be much ignored by [most] criminologists' (p. 171). ${ }^{18}$ Not dissimilar results have emerged from a French survey by Roché and Roux (2017), which explored how a general population sample judged 'police unfairness'. In a multivariate analysis, it was found that 'political attitudes and values emerged as the strongest predictors' (p. 524). More specifically, police were considered to be fairer by those holding right-wing political views, punitive attitudes, 'legalistic' values, and an intolerance towards crime.

However, the Roché-Roux study also raises a different issue about the possible influence of social background on judgements of legitimacy. A special subsample was drawn from those living in the large Seine-St. Denis area on the outskirts of Paris, which has a very high level of social deprivation, and a high proportion of ethnic minority and immigrant residents. Respondents from this area returned the lowest ratings on police fairness. But this result raises the fresh question: is the perceived police unfairness attributable to the cultural norms prevailing in this type of area, or to police behaviour in the area? Probably the answer is 'both', because in the survey both 'high police-initiated contact' and living in St. Denis were significantly associated with perceived police unfairness when other variables were controlled for. Similar findings emerged in a survey by Wesley Skogan (2006) in Chicago, where the dependent variable was confidence in the police; in this study, negative experiences with the police were statistically associated with lack of confidence, but so were 'neighbourhood dissatisfaction' and perceived problems in the area (drugs, social disorder). Most recently, after a complex and fascinating analysis of ethnicity and legitimacy in European Social Survey data, Bradford et al. (2018, pp. 69-70) report that while 'the experience of police activity seems to shape legitimacy in important ways', so too do 'economic, 
social and political marginalization', which in policy terms, they suggest, means that governments should consider not only improvements to policing, but also 'broader political responses to social exclusion'.

The analyses reported above clearly demonstrate that when citizens meet police officers, they do not do so with blank minds (and neither, of course, do the police come to such meetings in that fashion). The 'personal morality' which citizens bring to the meeting may be shaped, among other things, by their political or religious values; by their social status; by the culture and concerns of the area where they live; or by their previous experiences with the police. Given this, the question arises: do any of these background matters actually affect how citizens react in a specific encounter with police? The research evidence on this matter is still limited, but the answer to the question is clearly 'yes', as two studies - in different ways-help to illuminate.

The first of these studies provided evidence of a clear ethnic difference in citizens' reactions, based on their prior experiences with the police. Charles Epp and colleagues (2014) carried out research into police vehicle stops in the US, distinguishing between 'traffic-safety stops' and so-called 'investigative stops', in which officers target people whom they suspect of lawbreaking. The authors claim that, while officers shared with most ordinary citizens a bias against African Americans, this bias was not generally visible; however, it was apparent 'in the process of making investigatory stops' (p. 53). So, for example, a white woman living in a 'nice neighbourhood' is quoted as saying that she has been 'pulled over' much less often than her black neighbour and friend-'she's pulled over down at the corner more, and just asked "Do you live around here?"” (p. 122). By law, officers need a probable cause to order a stop, but the authors report that 'a minimal justification for the stop' is frequently voiced in African Americans' accounts of investigatory stops (p. 119). All this has significant consequences:

Most white drivers' narratives are of typical traffic-safety stops. White drivers never express a fear of the officer demanding to search the vehicle or make an arrest ... [By contrast] African American drivers ... focus on whether the stop was really about traffic enforcement or something else. Deana ... reported being 'scared' after being stopped twice within a few minutes 'for no reason, just to see where I was going', even though the officers were 'nice' and gave her no tickets ... Elizabeth ... characterized a stop as 'racial abuse' because the officers seemed less interested in the violation that they used to justify the stop-a late turn on a yellow light — than in checking her out and peering closely into her car.

(pp. 124-125)

The authors further report that it is common for African American drivers to express 'indignation' at the behaviour of 'polite but intrusively inquisitive officers' (p. 125), but that no such reaction was found among white drivers. Naturally, these matters are widely discussed among African Americans; and their 'shared 
knowledge of investigatory stops leads them to look carefully for signs that [their next] stop is an investigatory stop' (p. 120). Thus, there are very different immediate reactions when people are stopped. Epp et al. (2014) report that evaluations by whites are "framed within the range of typical possibilities in the "normal" traffic-safety stop: ticket versus warning'; by contrast, African Americans' evaluations 'are framed within a much wider range of possibilities: speeding stop versus intrusive investigation' (p. 126). It is also worth emphasising that, in this study, the indignation of African Americans subjected to investigatory stops was not mitigated by the politeness of officers; it was simply not the case that, as a former Chicago police chief once claimed, 'it's not what you do, it's how you do it' (Thacher 2019, p. 98). Procedural justice (including politeness) certainly matters, but so does non-discriminatory police practice (distributive justice). ${ }^{19}$

The second study was led by the late Peter ('Tank') Waddington, whose research team showed four video clips of real-life encounters between police and citizens (taken from BBC documentary programmes) to 34 focus groups in England. These groups were of varied age, ethnicity, and social status; for example, they included groups of Muslim women, mid-career professionals, and young offenders on probation. An early publication from the study describes in detail group members' reactions to just one of the video clips, which focused on a traffic stop by motorway police of a suspected car thief, and the aftermath of the stop as it became clear that the incident was more complex than the officers originally thought. The main conclusion was that the behaviour of the two police officers in this incident was often (although not invariably) assessed very differently by different people. ${ }^{20}$ What the authors described as 'issues of fairness and respect' surfaced repeatedly in the group discussions, but on many occasions different participants 'drew attention to the same occurrences within the video clip to justify entirely contradictory evaluations' (Waddington et al. 2015, p. 212). Further analysis showed that these divergent opinions 'could not readily be explained either by differences in the age, gender, ethnicity, or class composition of groups, or the purpose for which the group existed' (p. 221). The main reason for this perhaps surprising finding was that respondents

relied on their wider cognitive resources not only to interpret what they saw on screen, but also to infer what could not be seen and imagine past occurrences, current possibilities and future potentialities far removed from what they witnessed.

(p. 232, emphasis added)

This is valuable evidence that as citizens meet criminal justice authorities, they interpret the developing incident not only in terms of what is actually observed, but also in terms of inferences that-based on their background-they might draw about what they have seen. An example from a different videoed incident, reported in a later publication, is instructive in this regard. There was a general consensus that a police officer showed considerable patience when taking a 
statement from an elderly man who had just been robbed. However, during this process the officer looked at his wristwatch. In one group, this was interpreted by one observer as discourteous ('he was trying to rush it along'), but another thought the officer was fulfilling an administrative requirement to record the time on the statement (Waddington et al. 2017, p. 52).

There is much complexity here; and very possibly the issues identified by Waddington and colleagues might be related to Worden and McLean's (2017) findings of only a weak to moderate relationship between independently observed PJ and subjective PJ (see previous discussion). This is clearly an issue requiring further research.

\subsubsection{Situational contexts, procedural justice, and legitimacy}

We will explore the issue of situational contexts by considering the varying ways in which citizens meet police officers; the relationship between outcomes and judgements of PJ; and whether, in certain situations, people depart from the behaviour that might be expected in light of their 'deeply embedded core normative values' (Mehozay \& Factor 2017).

In the now extensive literature on assessments of PJ and legitimacy in policing encounters, it is frequently reported that contacts initiated by citizens themselves (often described as 'calls for service') are more positively evaluated than are policeinitiated contacts. Some useful detail is available from the Schenectady study by Worden and McLean (2017, Table 5, p. 138), where-it will be recalled-the available data included both 'observed' and 'subjective' measures of PJ for the same incidents. The authors conducted a series of regression analyses in which 'subjective procedural justice' was the dependent variable. In an early model, both observed procedural justice and observed procedural injustice were associated (in the expected directions) with subjective PJ, but so were encounters based on calls for service (positive) and arrests (negative) (Model II). Further analyses showed, first, that non-consensual stops and searches, either on the street or in a vehicle, were more negatively associated with PJ even than arrests ${ }^{21}$ (Models III and IV); and second that if the citizen had resisted the police during the encounter, he or she was particularly unlikely to perceive the encounter as procedurally just (Model V). In the final model (Model V), when all variables were included, observed procedural injustice still generated negative subjective perceptions of PJ, but observed procedural justice was no longer significant. The general picture that emerges from this survey is that citizens' perceptions of PJ seem to be inversely correlated with the police's use of coercive authority. This conclusion is supported by evidence from Waddington and colleagues' (2017) video clip analysis, which found that 'physical grappling with suspects' was 'not regarded with equanimity' by most members of the focus groups, especially when it involved more than one officer (p. 126). Since even the best police forces must, in order to do their job properly, sometimes use a degree of coercive authority (especially when dealing with citizen resistance, or with serious crimes ), these findings inevitably 
raise some policy dilemmas for police services: the uncomfortable truth seems to be that it is difficult to deliver optimal PJ when carrying out certain police tasks. ${ }^{22}$ However, it is important to note that by no means all police-initiated contact with citizens is coercive, and indeed community-oriented policing (COP) strategies explicitly set out to promote a different kind of proactive contact. A recent randomised field experiment yielded encouraging results as regards this type of contact; it was found that positive, non-enforcement COP visits by police to citizens' homes substantially improved public attitudes to the police, including legitimacy and willingness to cooperate, and these results were not limited to individuals with prior positive attitudes to the police (Peyton at al. 2019). Overall, therefore, the evidence suggests that the context of the police-citizen contact is an issue of some significance for subjective judgements of PJ and legitimacy.

Just as important as the above issues is the less well-explored situational issue of underenforcement; that is, situations where there is a lack of effective policing, although a credible 'basic legitimation expectation' for citizen protection is clearly present. A tragic example of this type of situation was described in an independent report into widespread child sexual abuse in the English town of Rotherham. The summary of the report makes clear the 'appalling nature of the abuse that [some] child victims suffered', which included 'being raped by multiple perpetrators [and] trafficked to other towns and cities'. The police, the inquiry concluded, 'gave no priority to [child sexual abuse], regarding many child victims with contempt'. Over a period of four years, three reports were made available to the police and the local government authority, and collectively these reports 'could not have been clearer in their description of the situation'. Unfortunately, however, the first report was 'effectively suppressed ... [while] the other two reports ... were ignored and no action was taken' (Jay 2014, p. 1). The victimised children and their families clearly considered that the police response lacked legitimacy. However, in making this judgement they were primarily concerned with the police's lack of effectiveness, and an apparent discrimination against this form of victimisation, rather than with a lack of procedural justice, although this was also present.

In the Rotherham example, those disadvantaged by underenforcement were socially powerless and vulnerable people. Alexandra Natapoff (2006) has argued that this structural characteristic is a recurring feature of underenforcement, which is

often linked with official discrimination ... legal failure, and the undemocratic treatment of the poor ... Conceived of as a form of public policy, underenforcement is a crucial distribution mechanism whereby the social good of lawfulness can be withheld.

The same author also notes that underenforcement can be observed not only (as in Rotherham) in weak state responses to victimisation, but also in weak 
responses to lawbreaking. This can take the familiar form of not pursuing cases against powerful people or corporations, but it can also occur when the lawbreakers are not powerful, but the offences they have committed have victimised vulnerable citizens. ${ }^{23}$

We turn now to a second aspect of social situations relevant to procedural justice and legitimacy, namely the relationship between process and outcome. Tyler and Meares (2019) have claimed that a 'central conclusion' of the research literature is that,

when people deal with authorities, their evaluations of the perceived fairness of the procedures through which authority is exercised influence legitimacy more strongly than does the perceived outcome of the encounter.

In our most recent joint paper, we endorsed this claim to the extent of saying that 'a powerful conclusion from the existing research is that ... citizens often prioritise procedural fairness' over perceived outcome favourability or fairness (Bottoms \& Tankebe 2017 , p. 75 , emphasis added). We also fully accept the encouraging evidence that fair procedures can act as a significant 'cushion of support against the potentially damaging effects of unfavorable outcomes' (Tyler $1990 / 2006$, p. 101). Nevertheless, and of relevance to the present discussion of situational differences, research has also shown that, in some circumstances, outcomes can matter rather more than the statement by Tyler and Meares would suggest; and three different issues are of relevance here.

First, do people actually know the outcomes delivered in other, similar, situations? For example, survey respondents who report having been the subject of a traffic stop might not know the outcomes for other stopped drivers-in which case, a claim of distributive unfairness of the outcome is hardly possible. By contrast, it has been shown that in long-term prisons-where news travels fast and the outcomes of most incidents are widely known-comparative outcome fairness is widely debated, and is of great importance (Sparks et al. 1996, pp. 303-311; discussed by Bottoms \& Tankebe 2012, p. 123). Second, some studies suggest that outcomes matter more to people's assessments of fairness when the stakes are high. For example, Jacobson et al. (2015) studied proceedings at an English Crown Court dealing with serious offences, where for defendants the potential consequences were usually much more serious than those at stake in most survey-based legitimacy research. The authors found that defendants were indeed interested in the fairness of procedures, but in the stark setting of the courtroom, the outcome of a case [conviction or acquittal; severity of sentence] ... is a crucial determinant of ... perceptions of legitimacy' (p. 166, emphasis added). Third, experience has confirmed Tyler's (1990/2006, p. 107) early speculation that "if a "fair" procedure continually delivers unfavorable outcomes, its fairness may ultimately come under scrutiny'. Exactly such a situation has been reported by Jenness and Calavita (2018) in a study of grievance procedures in California 
prisons, where 'prison officials ... uniformly lauded the [grievance] system as fair to prisoners' (p. 46) but where over 95\% of prisoners' grievances were denied (p. 45), creating considerable cynicism. From both their quantitative and qualitative analyses, the authors concluded that 'procedural justice does matter to ... prisoners'; however,

The prisoners in our study were above all concerned with how their grievance turned out-specifically, whether they were able to extract remedies from this institution that otherwise is responsible for so much daily deprivation. So dominant is this substantive dimension to their satisfaction that procedural dimensions are largely subordinate to it ... [In addition], the important relationship between outcome and satisfaction is further magnified when the stakes associated with the grievance are the highest.

(pp. 66-67).

None of the studies discussed in the previous paragraph argues that procedural justice was of no relevance in the situations that were researched. However, they all caution against assuming that procedural justice will always be more important than outcome favourability or perceived outcome fairness. Taken together they seem to have identified one situation where procedural justice will be dominant (citizens have little knowledge of outcomes other than their own) and two situations where perceptions of outcome might well be more important (high stakes; routine delivery of unfavourable outcomes). Empirical studies on this topic are still limited in quantity, but it ought to be possible for researchers to develop a fuller understanding of how procedures and outcomes seem to vary in their significance to citizens in different sets of social circumstances.

Section 4.3.1, above, focused among other things on citizens' 'deeply embedded core normative values'; by contrast, this section has considered the specifics of social situations. Clearly, any full 'substantivist' study of PJ and legitimacy will need to take account of both matters, and to assess how they might be interrelated. To close this section, we therefore draw attention to one recent study that carefully addresses this interaction.

Monica Bell (2016) became interested in the concept of 'legal cynicism', defined as a strong distrust of and cynicism about all legal authorities, especially the police; this worldview incorporates a moral rule that 'you don't snitch to the police'. She noted the extensive evidence that legal cynicism is pervasive among residents of poor, black neighbourhoods in the US; but she was also struck by some less frequently cited data, which show that residents of such areas have, even when one controls for crime rates, a higher rate of calls to police than residents of white, middle-class areas. To explore this apparent paradox, Bell conducted 50 lengthy qualitative interviews with poor African American mothers living in Washington, DC. She found plenty of evidence of legal cynicism in her sample, yet two-thirds of her respondents said that they had called the police at least once (p. 325). Why? Broadly, there were two main kinds of reason. One was 


\section{2}

what Bell calls 'officer exceptionalism'; that is, some women were willing to trust certain individual officers whom they had come to know personally, while still not placing any 'legitimacy or trust in the broader system' of policing (p. 329). Second, there were various circumstances in which the mothers might turn to the police because police seemed likely to offer better solutions than anyone else in specific situations. ${ }^{24}$ For example, one woman, while saying that she agreed with the 'street code' against calling the police, also reported that she had several times called police to help friends facing domestic violence, and to help control her teenage children (pp. 332-333). This example illustrates a further finding of Bell's study, namely that calls to the police were usually made about issues within or physically near to the women's homes, or those of their families or close friends, in an effort to regain or retain control of situations that were literally close to home. For more distant issues, such as drug trafficking and violent crime in the streets, the community norm against snitching held powerful sway, and the police were not called. Subtle findings such as these are important in reminding us of the value of qualitative as well as quantitative research methods; many surveys would simply record Bell's respondents as having negative perceptions of the police.

Monica Bell's research was not longitudinal, so she necessarily could not address the important question of how 'deeply embedded core normative values' might change in response to particular encounters or incidents. That is a further topic that requires research, although for some valuable 'informed speculation' on this issue, see Waddington et al. (2017, pp. 164-165).

\subsubsection{Moral contexts: 'good' versus 'right' relationships}

In an important paper on prisons, Alison Liebling (2011) differentiates between two kinds of relationships between prison officers and prisoners, described as 'good' and 'right' relationships. When talking about a particular prison, observers frequently ask whether that institution has good staff-prisoner relationships, but Liebling insists that this is not, ultimately, the correct question. She points out that having 'good' relations simply means that people are getting on with each other; however, a relationship between an officer and a prisoner may be 'good' but not 'right'. This can happen if, for example, the officer is turning a blind eye to the undercover importation of drugs into the prison, and/or if he or she is afraid to assert authority over some powerful prisoners. The problem is, essentially, that such relationships are 'too close or too informal, lacking boundaries and professional distance' (Liebling 2011, p. 491). ${ }^{25}$ By contrast, 'right' relationships are professional and ethical: the officer maintains humaneness, approachability, politeness, and so on, but is always aware of his or her professional obligations, including the need both to enforce and to abide by relevant laws and regulations.

It is important to note a theoretical point arising from this distinction. Following Hinsch (2010), many social scientists now distinguish between 
'empirical legitimacy' and 'normative legitimacy'. The 'good' versus 'right' distinction suggests that, as we have previously argued (Bottoms \& Tankebe 2012, pp. 156-158; Bottoms \& Tankebe 2017, pp. 48-51), while a predominantly empirical approach to the study of legitimacy is the appropriate starting point for social-scientific researchers, an exclusively empirical account is ultimately inadequate. However, rather than enter into this theoretical territory here, we will illustrate its implications from a recent empirical study.

Tankebe et al. (2019) conducted research with samples of drivers of commercial vehicles in two cities in Ghana. One of their regression analyses focused on self-reported traffic violations as the dependent variable. An initial analysis found that the variable 'personal experiences of police corruption' was associated with more traffic violations, but 'police fairness' (a standard set of PJ questions) was not significant. Further analyses explored possible interaction effects between 'personal experiences of police corruption' and 'police fairness', to determine whether the effects of the latter depended on the former. The results were significant, if disturbing. They suggested that the influence of police fairness on traffic violations depended on the moral context: where there was greater experience of corruption, 'police fairness' (better PJ) was associated with more, not fewer traffic violations. ${ }^{26}$ The research data did not allow further exploration of this fascinating finding, but - as the authors suggest - it is possible that underlying the data are 'good' rather than 'right' relationships: that is, the officers might have been willing to 'listen to what drivers have to say, explain decisions, show care for drivers' well-being, and avoid discriminatory stops of drivers, yet choose not to enforce the law on account of extra-legal considerations' (p. 11). Overall, therefore, the results of this study suggest that different moral contexts can generate different behavioural reactions to procedural justice; and in policy terms, we might wish to modify our advocacy of PJ by insisting that some (corrupt) versions of PJ are not to be encouraged.

\subsubsection{Comment}

In this section, we have traversed a great deal of ground rather quickly, but it is clear from the discussion that social and situational contexts can very significantly influence perceptions of PJ and legitimacy. Among the relevant issues in this respect are: citizens' deeply held political and moral views; neighbourhood norms; experiences of systematic distributive injustice; the nature of the current encounter with legal authorities (e.g. for police, calls for service versus arrests and searches); citizens drawing inferences about authorities' actions beyond what is actually observed; whether an encounter involves high stakes; experiences of underenforcement; setting aside one's normal perception of authorities in particular situations; and the distinction between 'good' and 'right' relationships. Many of these topics have yet to be explored in depth by scholars, so there remains a significant and challenging agenda for research. 


\subsection{Concluding discussion}

The importance of procedural justice for criminological analysis was first proposed by social psychologists. Social psychologists are, of course, concerned with social issues, but within that framework they focus especially on questions of individual psychology.

We are sociologists, not social psychologists, and in our first joint paper on legitimacy in criminology (which we titled 'Beyond Procedural Justice'), we summarised our position as one of 'going beyond - but emphatically not jettisoning the procedural justice framework' (Bottoms \& Tankebe 2012, p. 169). This stance has been interpreted by some as a rejection of procedural justice as a contributor to legitimacy, but this is incorrect. By 'going beyond' we meant simply that in our view other matters, of a more sociological character, had to be considered in order to explain empirical legitimacy adequately; but when we said we were 'not jettisoning' PJ, we meant just that. Accordingly, in our 2017 paper, we wrote that 'there is no doubt about its [PJ's] empirical importance in relation to police legitimacy' (Bottoms \& Tankebe 2017, p. 75). We remain of the same view today.

In that 2017 paper, we drew for the first time on Bernard Williams' conceptualisation of legitimacy. Within Williams' theoretical framework, we have no doubt that the exercise of procedural justice by state criminal justice agents is a 'basic legitimation expectation' (BLE) that citizens will justifiably express, bearing in mind the evidence that PJ touches crucially on citizens' 'social standing' and their 'feelings of security' within society (Tyler 1990/2006, p. 175). However, it is also pertinent to ask whether PJ will be the only such legitimation expectation that citizens will express to the state and its agents. Our answer is that it will not, and that some other matters (including distributive justice, lawfulness, and effectiveness) will also often constitute reasonable BLEs.

Even if that is so, however, perhaps these other matters will, empirically speaking, be regarded by citizens as much less important legitimation expectations than procedural justice? This seems to be the claim made by Tyler and Meares (2019) when they wrote in a recent paper that 'research points to evaluations of the justice or injustice of the procedures through which the police exercise their authority (i.e. procedural justice) as the key antecedents of legitimacy' (p. 71, emphasis added). However, if these authors are making such a claim, we would have to say that, in some circumstances, it is empirically doubtful, as various examples discussed in this chapter have shown (see for example Epp et al. 2014; Jay 2014; Tankebe et al. 2019). In our judgement, the available empirical evidence does not support the view that any one factor is in all circumstances the key basic legitimation expectation that citizens have of criminal justice systems. Instead, the evidence suggests that in different social contexts different legitimation expectations can be the most important. Accordingly, although in some social circumstances the exercise of PJ might be no more than 'palliative' (see note 19 below), in other circumstances it could be of vital importance. For example, if in a given social area there is a problem of heightened crime and insecurity, improved police effectiveness might be the main route to better legitimacy; but once that problem is resolved, issues of 
procedural justice-such as the respectful treatment of suspects and victims, and greater transparency in decisions-might well replace effectiveness as the most important factor within the structure of legitimacy. ${ }^{27}$ This contextual variability means, in our view, that PJ scholarship should in future pay greater attention to the social and situational circumstances in which PJ is delivered; ${ }^{28}$ and, as our discussion in Section 4.3 of this chapter has hopefully demonstrated, understanding these circumstances fully will be a complex undertaking. Meeting this research agenda will accordingly require the development of a stronger qualitative research literature than currently exists (Tankebe 2014, p. 254), to set alongside the survey work that has so far been dominant in this field of scholarship.

\section{Notes}

l It is important to distinguish these two meanings of the word 'normative' because-as described for example by Meyerson and Mackenzie (2018) - it is possible to formulate instrumental theories of PJ (such as utilitarianism) that are normative in the first but not the second sense. By contrast, social scientists studying PJ usually say that their work is descriptive and explanatory, and therefore not concerned with 'normative ethics' in the first sense. However, within this descriptive/explanatory framework, they draw a distinction between normative and instrumental explanations of human behaviour. Tom Tyler (1990/2006, p. 3) succinctly described this distinction as a contrast between 'the influence of what people regard as just and moral' [normative] and the influence of 'what is in [people's] self-interest' [instrumental].

2 Arising from this definition, we should note an important distinction between 'legitimacy' and what has been called 'dull compulsion' or 'fatalism'. Fatalism exists where there is a marked power imbalance between power-holders and their subjects, and people obey simply because they fatalistically accept that the structures of power, wealth and/or status are inexorably stacked against them (Lockwood 1992, p. 43). This is very different from an uncoerced acknowledgment that power is held rightfully.

3 There can however be a problem with this 'realist' theoretical approach where the content of a citizen-approved BLE is regarded as morally wrong by the governing authority. For a full discussion of this issue see Bottoms and Tankebe (2017).

4 This quotation is taken from a paper on PJ in the specific context of policing. In four places (indicated by square brackets) we have substituted 'authorities' for the original of 'the police'.

5 There has been some lively recent controversy concerning whether the causal links in this proposed sequence have been adequately demonstrated empirically (see Nagin \& Telep 2017; Tyler 2017). This debate is, however, of limited importance for the purposes of this chapter, because the issue of compliance with law (the final stage in the projected sequence, and the one of particular interest to critics) is outside the scope of our discussion.

6 The insights of the Group Value Model (GVM) were subsequently developed in the 'Group Engagement Model' (Tyler \& Blader 2003). This added to the GVM an explanation for why PJ shapes co-operation in groups and societies (p. 352) - a topic that (see note 5 above) is not our focus in this chapter.

7 In a previous paper (Bottoms \& Tankebe 2017, p. 76) we have also tentatively suggested that there may be conceptual links between the group value model of PJ and Axel Honneth's philosophical work on the recognition of individuals (see Honneth 1995; Zurn 2015). 
8 Although the reference here is to a single 'audience', elsewhere in the same paper we make clear that there can be several different audiences for a claim to legitimate authority. For example, when introducing a new operational policy, the Director of Prisons for a given state will certainly have to consider how prisoners will evaluate the justice of the policy; but she will also need to take into account the views of her political masters, and those of the prison staff who will have to implement the policy.

9 Note also that the nature of legitimacy dialogues can change significantly over time. For example, in 2019 Hong Kong experienced a series of conflicts on the streets between protestors and authorities, extending over several weeks. Initially, the demonstrators focused on grievances concerning an extradition law, but later their complaints became more general. Police behaviour was not at first a cause of complaint by protestors, but it later became so as they claimed that police had behaved inappropriately when dealing with some of their demonstrations.

10 See, however, the recent critique of PJ by David Thacher (2019), a central claim of which is that 'procedural justice leaves out lawfulness' (p. 99).

11 See also the comments by David Beetham (1991/2013, p. 137) in the context of the legitimacy of state government more generally: 'the performance of government makes a significant difference to, and forms a necessary component of, its legitimacy...After all, how can the enormous powers of the state be at all justified, or people obliged to obey it, unless it fulfil requirements necessary to the society and their own well being, and that it fulfil them effectively?'

12 An example is the situation in County Donegal, Republic of Ireland, described by Conway (2014) and summarised in Bottoms and Tankebe (2017, p. 86). Documented findings of serious police lawlessness and corruption had little effect on public confidence in the police in that county, for reasons connected with wider features of Irish history and politics.

13 The study included three ethnic groups of roughly equal size: blacks, Hispanics and whites. The only statistically significant differences between groups were that, as compared with black respondents, Hispanics were more likely to mention 'honesty' and less likely to mention 'fairness'.

14 To create the categories used in the research, the research team deliberately hired a research assistant who was not familiar with the academic literatures on legitimacy and trust. From the responses, this assistant created the category 'fairness', which included both procedural and distributive fairness.

15 On the first point, see Dunbar (2014) on the importance of group living within the complex story of human evolution. On the second point, see the classic analysis by the legal theorist Karl Llewellyn (1940) of the need for all social groups to develop ways of handling certain 'law-jobs', if the group is to function well. Among these law-jobs is 'The Say', which covers questions of who is given authority to make different kinds of decisions within the group.

16 On the theoretical importance of macro-social issues wihin democratic legitimacy dialogues, see Loader and Sparks (2013). For a vivid example of the relevance of such issues within a high-profile debate about the legitimacy of various practices in the Illinois prison system in the 1960s, see Jacobs (1977), summarised in Bottoms and Tankebe (2012, pp. 167-168).

17 The 'religious-traditional' factor was not related to legitimacy, possibly because many of the relevant questionnaire items 'measure religious practice instead of directly measuring religious-traditional core normative values' (p. 171). The results for the ethno-national factor bear some similarity to Tyler's (2000) findings that, within the U.S., citizens who identify more strongly with a particular ethnic group (rather than with American society as a whole) are less influenced by considerations of procedural justice and more influenced by whether policies are favourable to their ethnic group. This is because 'they identify more strongly with subgroups than with society, and/or view the authorities as representatives of a group to which they do not belong' (p. 983). 
18 As an exception to this generalisation, the authors cite the work of Anthony Bottoms on compliance; see now Bottoms (2019). See also Sato (2018, pp. 108, 121) on habit as a possible mechanism for co-operation with the police in Japan.

19 This point was recognised by Tom Tyler in a back-cover endorsement of the study by Epp and colleagues on police stops. Tyler wrote that 'polite and respectful police demeanor, while to some extent palliative, cannot assuage the damaging effects of the widespread and systematic use of this policing technique on the minority community'

20 An important exception to the dissensus was a 'remarkable agreement' that at the time of the stop on the motorway, the first officer to approach the stopped vehicle should have politely asked the driver to alight from the car. Instead, he reached into the car and began tussling with the driver, saying 'Get out before I drag you out' (Waddington et al. 2017, pp. 98-99). Note that here the focus groups are strongly endorsing a PJ approach.

21 By contrast, in citizen-initiated contacts, a rapid police response time was positively associated with subjective procedural justice (Model IV).

22 Waddington et al. (2017, p. 126) found that, in assessing police use of non-lethal force, members of the public in their focus groups 'relied, as the law does, on whether [it] is "reasonable"'. However, there was often marked dissensus as to whether the force used in a particular incident was in fact reasonable.

23 A well-known example of this is the case of Stephen Lawrence, a young black man who was murdered in the streets of south London in 1993. A commission of inquiry eventually concluded that the police's failure to take the case seriously had been occasioned by what the commission called 'institutional racism' defined as 'the collective failure of an organisation to provide an appropriate and professional service to people because of their colour, culture or ethnic origin ... [exemplified by] unwitting prejudice, ignorance, thoughtlessness and racist stereotyping which disadvantage minority ethnic people' (Macpherson Inquiry 1999, para. 6.34).

24 In more detail, Bell distinguished cases where (i) women thought that police would be the most effective agency to handle a particular problem ('domain specificity'); or (ii) they foresaw some beneficial outcome in a given situation ('therapeutic consequences'); or (iii) they turned to the police in a quest for protection or to secure leverage with other power-holders ('institutional navigation').

25 There are, of course, parallels to this within policing: see for example Muir's discussion of officers who adopt a 'reciprocator' role, aiming for a reputation as a 'Joe Good Guy' and with a tendency to 'bestow upon the citizen the reciprocal of [their] authority, [their] leniency, the power not to hurt' in exchange for personal profit (Muir 1977, p. 293).

26 Interestingly, the results were the same when the authors substituted 'vicarious experiences of police corruption' for 'personal experiences of police corruption'

27 See, for example, Chen (1997) who argues that legitimacy crises sometimes arise for authoritarian governments even when they are effective in producing economic prosperity. The reason is the emergence of new demands-such as pressure for voice and participation in governance-to which such governments might be ill-prepared to respond.

28 For a congruent message, see Roché and Oberwittler (2018).

\section{References}

Akinlabi, OM 2018, 'Why do Nigerians cooperate with the police?: legitimacy, procedural justice and other contextual factors in Nigeria', in D Oberwittler \& S Roché (eds.), Police-citizen relations across the world: comparing sources and contexts of trust and legitimacy, Routledge, London. 
Beetham, D 1991/2013, The legitimation of power, first edition 1991 Macmillan, London; second edition with new introduction and new Part III 2013, Palgrave Macmillan, Basingstoke.

Beetham, D 2013, 'Revisiting legitimacy, twenty years on', in J Tankebe \& A Liebling (eds.), Legitimacy and criminal justice: an international exploration, Oxford University Press, Oxford.

Bell, MC 2016, 'Situational trust: how disadvantaged mothers reconceive legal cynicism', Law \& Society Review, vol. 50, no. 2, pp. 314-47.

Bottoms, AE 2019, 'Understanding compliance with laws and regulations: a mechanism-based approach', in M. Krambia-Kapardis (ed.) Financial compliance: issues, concerns and future directions, Palgrave Macmillan, Basingstoke.

Bottoms, AE \& Tankebe, J 2012, 'Beyond procedural justice: a dialogic approach to legitimacy in criminal justice', Journal of Criminal Law and Criminology, vol. 102, no. 1, pp. 119-70.

Bottoms, AE \& Tankebe, J 2017, 'Police legitimacy and the authority of the state', in A du Bois-Pedain, M Ulväng \& P Asp (eds.), Criminal law and the authority of the state, Hart Publishing, Oxford.

Bradford, B, Huq, A, Jackson, J \& Roberts, B 2014, 'What price fairness when security is at stake?: police legitimacy in South Africa', Regulation \& Governance, vol. 8, no. 2, pp. 246-68.

Bradford, B, Jackson J \& Hough M 2018, 'Ethnicity, group position and police legitimacy: early findings from the European social survey', in D Oberwittler \& $S$ Roché (eds.), Police-citizen relations across the world: comparing sources and contexts of trust and legitimacy, Routledge, London

Chen, F 1997, 'The dilemma of eudaemonic legitimacy in post-Mao China', Polity, vol. 29 , no. 3, pp. 421-39.

Coicaud, JM 2002, Legitimacy and politics: a contribution to the study of political right and political responsibility, Cambridge University Press, Cambridge.

Conway, V 2014, Policing twentieth century Ireland: a history of An Garda Siochana, Routledge, London.

Dunbar, R 2014, Human evolution, Penguin, London.

Dunn, J 2013, 'Legitimacy and democracy in the world today', in J Tankebe \& A Liebling (eds.), Legitimacy and criminal justice: an international exploration, Oxford University Press, Oxford.

Epp, CR, Maynard-Moody, S \& Haider-Markel, D 2014, Pulled over: how police stops define race and citizenship, University of Chicago Press, Chicago.

Granovetter, M 1985, 'Economic action and social structure: the problem of embeddedness', American Journal of Sociology, vol. 91, no. 3, pp. 481-510.

Hawthorn, G 2005, 'Introduction', in B Williams, In the beginning was the deed: realism and moralism in political argument, Princeton University Press, Princeton.

Hinsch, W 2010, 'Justice, legitimacy, and constitutional rights', Critical Review of International Social and Political Philosophy, vol. 13, no. 1, pp. 39-54.

Honneth, A 1995, The struggle for recognition: the moral grammar of social conflicts, Polity Press, Cambridge.

Jacobs, JB 1977, Stateville: the penitentiary in mass society. Chicago University Press, Chicago.

Jacobson, J, Hunter, G \& Kirby, A 2015, Inside Crown Court: personal experiences and questions of legitimacy, Policy Press, Bristol. 
Jay, A 2014, Independent inquiry into child sexual exploitation in Rotherham. Available at https://www.rotherham.gov.uk/downloads/file/279/independent-inqui ry-into-child-sexual-exploitation-in-rotherham [Accessed December 2019]

Jenness, V \& Calavita, K 2018, “'It depends on the outcome”: prisoners, grievances, and perceptions of justice', Law \& Society Review, vol. 52, no. 1, pp. 41-72.

Jonathan-Zamir, T, Mastrofski, SD \& Moyal, S 2015, 'Measuring procedural justice in police-citizen encounters', Justice Quarterly, vol. 32, no. 5, pp. 845-71.

Kearns, EM, Ashooh, E \& Lowrey-Kinberg, B 2019, 'Racial differences in conceptualizing legitimacy and trust in police', American Journal of Criminal Justice, vol. 45, no. 2, pp. 190-214.

Liebling, A 2011, 'Distinctions and distinctiveness in the work of prison officers: legitimacy and authority revisited', European Journal of Criminology, vol. 8, no. 6, pp. 484-99.

Lind, EA \& Tyler, TR 1988, The social psychology of procedural justice, Plenum Press, New York.

Llewellyn, KN 1940, 'The normative, the legal, and the law-jobs: the problem of juristic method', Yale Law Journal, vol. 49, no. 8, pp. 1355-1400.

Loader, I \& Sparks, R 2013, 'Unfinished business: legitimacy, crime control and democratic politics', in J Tankebe \& A Liebling (eds.), Legitimacy and criminal justice: an international exploration, Oxford University Press, Oxford.

Lockwood, D 1992, Solidarity and schism: the problem of disorder in Durkbeim and Marxist sociology, Clarendon Press, Oxford.

MacCormick, N 2007, Institutions of law, Oxford University Press, Oxford.

Macpherson Inquiry, 1999, The Stephen Lawrence Inquiry: report of an inquiry by Sir William Macpherson of Cluny, Cm 4262, The Stationery Office, London.

McCluskey, JD, Uchida, CD, Solomon, SE, Wooditch, A, Connor, C \& Revier, L 2019, 'Assessing the effects of body-worn cameras on procedural justice in the Los Angeles Police Department', Criminology, vol. 57, no. 2, pp. 208-236.

Mehozay, Y \& Factor, R 2017, 'Deeply embedded core normative values and legitimacy of law enforcement authorities', Journal of Research in Crime and Delinquency, vol. 54, no. 2, pp. 151-180.

Meyerson, D \& Mackenzie, C 2018, 'Procedural justice and the law', Philosophy Compass vol. 13, no. 12, pp. 1-11.

Muir, WK 1977, Police: streetcorner politicians, University of Chicago Press, Chicago.

Nagin, D \& Telep, C 2017, 'Procedural justice and legal compliance', Annual Review of Law and Social Science, vol. 13, pp. 5-28.

Natapoff, A 2006, 'Underenforcement', Fordham Law Review, vol. 75, no. 3, pp. $1715-76$.

Nawaz, A \& Tankebe, J 2018, 'Tracking procedural justice in stop and search encounters: coding evidence from body-worn video cameras', Cambridge Journal of Evidence-Based Policing, vol. 2, pp. 139-163.

Peffley, M \& Hurwitz, J 2010, Justice in America: the separate realities of blacks and whites, Cambridge University Press, Cambridge.

Peyton, K, Sierra-Arévalo, M \& Rand, DG 2019, 'A field experiment on community policing and police legitimacy', Proceedings of the National Academy of Sciences, vol. 116, no. 40, pp. 19894-19898.

Roché, S \& Oberwittler, D 2018, 'Towards a broader view of police-citizen relations: how societal cleavages and political contexts shape trust and distrust, legitimacy and 
illegitimacy', in D Oberwittler \& S Roché (eds.), Police-citizen relations across the world: comparing sources and contexts of trust and legitimacy, Routledge, London.

Roché, S \& Roux, G 2017, 'The "silver bullet" to good policing-a mirage: an analysis of the effects of political ideology and ethnic identity on procedural justice', Policing: An International Journal of Police Strategies and Management, vol. 40, no. 3, pp. 514-28.

Sato, M 2018, 'Police legitimacy and public cooperation: is Japan an outlier in the procedural justice model?', in D Oberwittler \& S Roché (eds.), Police-citizen relations across the world: comparing sources and contexts of trust and legitimacy, Routledge, London.

Skogan, WG 2006, 'Asymmetry in the impact of encounters with police', Policing \& Society, vol. 16, no. 2, pp. 99-126.

Sparks, R, Bottoms, A \& Hay, W 1996, Prisons and the problem of order, Clarendon Press, Oxford.

Sunshine, J \& Tyler, TR 2003, 'The role of procedural justice and legitimacy in shaping public support for policing', Law \& Society Review, vol. 37, no. 3, pp. 513-48.

Tankebe, J 2009, 'Public cooperation with the police in Ghana: does procedural fairness matter?', Criminology, vol. 47, no. 3, pp. 1265-1293.

Tankebe, J 2013, 'Viewing things differently: the dimensions of public perceptions of police legitimacy', Criminology, vol. 51, no. 1, pp. 103-135.

Tankebe, J 2014, 'Police legitimacy', in MD Reisig \& R Kane (eds.), Oxford handbook of policing, Oxford University Press, New York.

Tankebe, J, Boakye, KE \& Amagnya, MA 2019, 'Traffic violations and cooperative intentions among drivers: the role of corruption and fairness', Policing and Society. doi:10.1080/10439463.2019.1636795

Thacher, D 2019, 'The limits of procedural justice', in D Weisburd \& A Braga (eds.), Police innovation: contrasting perspectives, Oxford University Press, Oxford.

Tyler, TR 1990/2006, Why people obey the law, first edition 1990 Yale University Press, New Haven; second edition 2006 (with afterword) Princeton University Press, Princeton.

Tyler, TR 2000, 'Multiculturalism and the willingness of citizens to defer to law and to legal authorities', Law \& Social Inquiry, vol. 25, no. 4, pp. 983-1019.

Tyler, TR 2017, 'Procedural justice and policing: a rush to judgment?', Annual Review of Law and Social Science, vol. 13, no. 1, pp. 29-53.

Tyler, TR \& Blader SL 2003, 'The Group Engagement Model: procedural justice, social identity and co-operative behavior', Personality and Social Psychology Review, vol. 7 , no. 4 , pp. 349-361.

Tyler, TR \& Meares TL 2019, 'Procedural justice in policing', in D Weisburd \& A Braga (eds.), Police innovation: contrasting perspectives, Cambridge University Press, Cambridge.

Waddington, PAJ, Williams, K, Wright, M \& Newburn, T 2015, 'Dissension in public evaluations of the police', Policing and Society, vol. 25, no. 2, pp. 212-235.

Waddington, PAJ, Williams, K, Wright, M \& Newburn, T 2017, How people judge policing, Oxford University Press, Oxford.

Williams, B 2005, In the beginning was the deed: realism and moralism in political argument, Princeton University Press, Princeton.

Worden, RE \& McLean, SJ 2017, Mirage of police reform: procedural justice and police legitimacy. University of California Press, Oakland.

Zurn, C 2015, Axel Honneth, Polity Press, Cambridge. 